\title{
Operasie Packer, Maart-April 1988, Suidoos- Angola: Tumpo, Tumpo en nogmaals Tumpo!!! Operation Packer, March-April 1988, South Eastern Angola: Tumpo, Tumpo and once more Tumpo!!!
}

\author{
Gerhard J. J. OOSThuizen \\ Vakgroep Geskiedenis en Antieke Kultuur \\ Potchefstroomkampus \\ Noordwes-Universiteit \\ Potchefstroom \\ E-pos: 10061797@nwu.ac.za
}

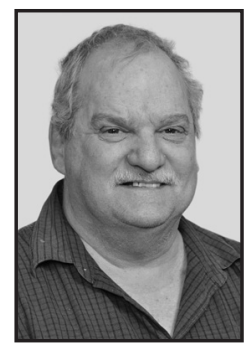

Gerhard Oosthuizen
Gerhard Oosthuizen is 'n medeprofessor in die Fakulteit Lettere en Wysbegeerte (Vakgroep Geskiedenis en Antieke Kultuur) van die Noordwes-Universiteit se Potchefstroomkampus. Sy navorsingsbelangstellings behels Namibiese geskiedenis, grondkwessies in die Noordwesprovinsie en Suid-Afrikaanse militêre geskiedenis. Hy fokus in besonder op die sogenaamde "Bosoorlog" (1966-1989) en het reeds verskeie artikels rakende die konvensionele fase van dié oorlog die lig laat sien.
Gerhard Oosthuizen is an associate professor in the Faculty of Arts (Subject group History and Ancient Culture) at the Potchefstroom Campus of the North-West University. His research interests include Namibian history, land issues in the North West Province of South Africa and South African military history. In particular, he focuses on the so-called "Bush War" (1966-1989) and has published various articles about the conventional phase of that war.

\begin{abstract}
Operation Packer, March-April 1988, South Eastern Angola: Tumpo, Tumpo and once more Tumpo!!!

In addition to securing the União Nacional para a Independêcia Total de Angola (UNITA) strongholds at Mavinga and Jamba, Operations Modular, Hooper and Packer (1987-1988) also intended to destroy all Forças Armadas Populares de Libertação de Angola (FAPLA) brigades east of the Cuito River, or to drive them to the west across the river. During operations Modular and Hooper the South African Defence Force (SADF)-UNITA allies succeeded in effectively stopping the advance of the Movimento Popular de Libertação de Angola (MPLA) allies. The primary objective to destroy all FAPLA brigades east of the Cuito River or to drive them across the river at least, could not fully be realised, however. During Operation Hooper, two failed attacks were launched on Tumpo within the scope of about two weeks-each time from the same direction or line of advance. This article focuses on the third and final South African Defence Force (SADF)-UNITA attack on Tumpo and the claim by Colonel Jan
\end{abstract}


Breytenbach, former commander of 32 Battalion, that "By early the next morning [23 March $1988]$ they had driven the $25^{\text {th }}$ Brigade from their positions and taken Tumpu [sic]. This clearly demonstrated that well planned, well led and well coordinated night [sic] attacks by well trained infantary seldom fail."

The task of launching a third attempt to conquer Tumpo would be undertaken by elements of citizen force units, 32 Battalion and four UNITA infantry battalions under the command of 82 South African Mechanised Brigade (SA Mech Bde). The citizen force units in question were Regiment Mooi River, Regiment President Steyn, Regiment De la Rey, Regiment Great Karoo, Regiment Potchefstroom University, 44 Parachute Brigade, 13 Field Engineering Regiment, 19 Rocket Regiment and 7 Anti-Aircraft Regiment. The maximum number of UNITA infantry had to join the attack, mainly to draw fire, to identify targets and to restrict SADF losses to the minimum. To justify the continued battle, the SADF provided five reasons to leadership and troops: The MPLA was illegally in power in Angola; Angola was used as a firm base by the Union of Socialist Sowjet Republics (USSR) to fight against the Republic of South Africa (RSA) and South West Africa (SWA); the USSR supported the MPLA and the ANC; and UNITA served as a buffer zone for attacks against SWA and therefore the SADF was indirectly fighting for UNITA and directly for the RSA. It would also give the SADF an opportunity to test new weaponry. Several dominant factors, however, led to the failure of the third attack on Tumpo: A lack of creative thinking, by repeating almost exactly the same plan of attack and line of advance of the failed second attack on Tumpo; the lack of an informed logistics system (e.g. shortage of diesel and mechanical readiness of vehicles and equipment); well-entrenched and well-equipped MPLA forces; inadequate intelligence (especially regarding the second minefield); almost impassable sandy and forested terrain; unmanned observer posts; largely insufficient preparation and training of citizen force units; the tension and lack of trust between citizen force units and SADF permanent force officers; and international pressure to withdraw from Angola.

The morale of the SADF-UNITA troops reached a low after the third failed attempt. The MPLA morale, in contrast, was particularly high, after successfully defending Tumpo and seizing three SADF tanks. The tanks which were abandoned by the SADF, had strong propaganda value for the MPLA forces. One of the tanks was towed to 25 Battalion's positions while the others were protected by positions to prevent the SADF forces from reaching them. Foreign journalists were even flown in to view the SADF tanks. In addition, amplified broadcasting was used to announce far and wide that the three tanks were in FAPLA hands and that an Afrikaans-speaking SADF soldier was captured.

As in previous operations, the $S A D F$ did not realise the importance of psychological debriefing. Many traumatised SADF soldiers suffered from post-traumatic stress, which put a damper on their vitality. UNITA suffered serious personnel losses, especially the troops who had moved with the tanks. In addition, many soldiers of the two UNITA battalions who attacked on the western bank, died in action. In contrast, the SADF forces suffered no losses. The objective to minimise SADF losses through the maximum utilisation of UNITA troops, was therefore fully realised.

KEY WORDS: $\quad$ Operation Packer; SAW; UNITA; FAPLA; MPLA; SWAPO; Angola; Cuito Cuanavale; Tumpo; Mavinga; Jamba; Cuba

TREFWOORDE: Operasie Packer; SAW; UNITA; FAPLA; MPLA; SWAPO; Angola; Cuito Cuanavale; Tumpo; Mavinga; Jamba; Kuba 


\section{OPSOMMING}

Operasies Moduler, Hooper en Packer (1987-1988) het, benewens die beveiliging van die União Nacional para a Independência Total de Angola/Nasionale Unie vir Volkome Onafhanklikheid vir Angola (UNITA)-vestings Mavinga en Jamba, beoog om alle Forças Armadas Populares de Libertação de Angola/Die leër van die Angolese MPLA-regering (FAPLA)-brigades oos van die Cuito-rivier te vernietig of ten minste weswaarts oor dié rivier te verdryf. Tydens Operasies Moduler en Hooper kon die Suid-Afrikaanse Weermag (SAW)UNITA-bondgenote daarin slaag om die FAPLA-bondgenote se aanmars effektief te stuit. Die primêre doelwit om alle FAPLA-brigades oos van die Cuito-rivier te vernietig of ten minste oor die rivier te verdryf, kon egter nie verwesentlik word nie. Tydens Operasie Hooper is twee mislukte aanvalle binne die bestek van sowat twee weke op Tumpo geloods - elke keer vanuit dieselfde rigting of aanmarslyn. Hierdie artikel fokus op die derde en laaste SAW-UNITAaanval op Tumpo en die aanspraak van kolonel Jan Breytenbach, oud-bevelvoerder van 32 Bataljon, dat "By early the next morning [23 March 1988] they had driven the $25^{\text {th }}$ Brigade from their positions and taken Tumpu [sic]. This clearly demonstrated that well planned, well led and well coordinated night [sic] attacks by well trained infantary seldom fail." Verskeie dominante faktore het egter die derde aanslag op Tumpo gekelder: 'n Gebrek aan kreatiewe denke deur bykans dieselfde aanvalsplan en aanmarslyn van die mislukte tweede Tumpo-aanval te herhaal; die gebrek aan 'n oorwoë logistieke stelsel (byvoorbeeld die tekort aan diesel en meganiese paraatheid van voertuie en toerusting); deeglik verskansde en toegeruste FAPLAmagte; ontoereikende intelligensie (veral betreffende die tweede mynveld); bykans onbegaanbare sanderige en digbeboste terrein; onbemande observasieposte; grotendeels onvoldoende voorbereiding en opleiding van burgermageenhede; die gespanne en gebrekkige vertrouensverhouding tussen burgermageenhede en SAW-staandemagoffisiere; en internasionale druk om uit Angola te onttrek.

\section{AGTERGROND}

Na die onafhanklikwording van Angola in November 1975 het drie rebelle-organisasies União Nacional para a Independência Total de Angola/Nasionale Unie vir Volkome Onafhanklikheid vir Angola (UNITA), Movimento Popular de Libertação de Angola/ Volksbeweging vir die Bevryding van Angola (MPLA) en Frente Nacional de Libertação de Angola/Nasionale Front vir die Bevryding van Angola (FNLA) - mekaar opnuut die stryd aangesê. Dié burgeroorlog het hom teen die agtergrond van die Koue Oorlog (1945-1990) afgespeel. Suid-Afrika, gesteun deur die Verenigde State van Amerika (VSA), het UNITA en die FNLA ondersteun, terwyl die Unie van Sosialistiese Sowjetrepublieke (USSR) en sy satellietstaat, Kuba, die Angolese MPLA-regering ondersteun het. Laasgenoemde twee state het die Kommunistiesgesinde South West African People's Organisation (SWAPO) ondersteun en in staat gestel om Suidwes-Afrika (Namibië) vanuit Suid-Angola binne te dring. In reaksie hierop het die Suid-Afrikaanse Weermag (SAW) sedert 1975 verskeie transgrensoperasies van stapel gestuur om enige insypeling vanuit dié geweste in die kiem te smoor.

Weens die bedreiging van die militêre vleuel van MPLA, Forças Armadas Populares de Libertação de Angola/Die leër van die Angolese MPLA-regering (FAPLA), het Jonas Savimbi, president van UNITA, gedurende Mei 1987 die SAW dringend versoek om bystand te verleen. Die SAW het gevolglik ter ondersteuning verskeie transgrensoperasies geloods. Operasies Moduler, Hooper en Packer (1987-1988) het, benewens die beveiliging van die UNITA- 
vestings Mavinga en Jamba, beoog om alle FAPLA-brigades ${ }^{1}$ oos van die Cuito-rivier te vernietig of ten minste weswaarts oor die Cuito-rivier te verdryf. Tydens Operasies Moduler en Hooper kon die SAW-UNITA-bondgenote daarin slaag om die FAPLA-bondgenote se aanmars effektief te stuit. Die primêre doelwit om alle FAPLA-brigades oos van die Cuitorivier te vernietig of ten minste oor dié rivier te verdryf, kon egter nie ten volle verwesentlik word nie. Tydens Operasie Hooper is twee mislukte aanvalle binne die bestek van sowat twee weke op die FAPLA-vesting in Tumpo geloods - elke keer vanuit min of meer dieselfde rigting of aanmarslyn. ${ }^{2}$

Hierdie artikel fokus op die derde en laaste SAW-UNITA-aanval op Tumpo en op die aanspraak van kolonel Jan Breytenbach, oud-bevelvoerder 32 Bataljon, dat "By early the next morning [23 March 1988] they had driven the $25^{\text {th }}$ Brigade from their positions and taken Tumpu [sic]. This clearly demonstrated that well planned, well led and well coordinated night [attacks] by well trained infantary seldom fail. ${ }^{\prime 3}$ Die Breytenbach-aanspraak is egter nie uniek nie en is deur verskeie belanghebbende persone ondersteun. ${ }^{4}$

Die twee mislukte pogings om Tumpo te verower het 'n demoraliserende effek op die betrokke SAW-eenhede gehad. Die SAW-leierselement het gevolglik verskeie ontlontingpogings aangewend om die "persepsie onder eiemagte dat ons verloor het op Tumpo weens die terugtrekking" in die kiem te smoor. Ook die kapelane het opdrag ontvang om tydens bidparades die "verloor-persepsie" ten sterkste te beveg. Die aanspraak van die SAWleierselement dat dié pogings besonder effektief was, hou egter nie water nie. ${ }^{5}$

Die taak om 'n derde poging aan te wend om Tumpo te verower, sou deur elemente van burgermageenhede, 32 Bataljon en vier UNITA-infanteriebataljons onder bevel van 82 SuidAfrikaanse Gemeganiseerde (82 SA Meg Bde) Brigade aangepak word. Die betrokke burgermageenhede was Regiment Mooirivier, Regiment President Steyn, Regiment De la Rey, Regiment Groot Karoo, Regiment Potchefstroom Universiteit, 44 Valskerm Brigade, 13 Veldgenieregiment, 19 Vuurpylregiment en 7 Lugafweerregiment. Die maksimum aantal UNITAinfanteriste moes aan die aanval deelneem, hoofsaaklik om vuur te trek, teikens vas te stel en die SAW-verliese tot die minimum te beperk. ${ }^{6}$

Hewige reënstorms met gepaardgaande oorstromings het die beweging van sekere eenhede gekortwiek. Só het Regiment Mooirivier byvoorbeeld op 20 Februarie 1988 per bus na 7 Divisie Mobilisasiesentrum te Bloemfontein vertrek. Kaptein Japie Venter en luitenant Kobus Taljaardt het die inklaringsproses in 'n sopnat Bloemfontein hanteer. Gedurende die mobilisasiefase het dit so gereën dat sommige tente kniediep onder water was en ander inmekaargestort het. In oorleg met die personeel van 7 Mobilisasiesentrum is een voertuigloods

Ingeslote Kubaanse magte en Russiese raadgewers.

G.J.J. Oosthuizen, "Die Suid-Afrikaanse Weermag en die 'stryd' om Cuito Cuanavale: fases 2, 3 en 4 van Operasie Moduler, Oktober - Desember 1987 (New Contree, nommer 61, Mei 2011), pp 32-35; G. Oosthuizen, "The South African Defence Force and Operation Hooper, Southeast Angola, December 1987 to March 1988" (Scientia Militaria, number 2, 2014), p 85.

3 J. Breytenbach. 1990. They live by the sword. Alberton: Lemur, pp 257-258.

$4 \quad$ Kyk byvoorbeeld J. Geldenhuys (samesteller). ca 2011. Ons was daar: Wenners van die oorlog om Suider-Afrika. Pretoria: Kraal-Uitgewers), p 415.

$5 \quad$ Suid-Afrikaanse Weermag Dokumentasiesentrum (SANWD), Pretoria, JF Huyser-versameling (JFH), Houer 89, [Lêer 418], Ops Hooper Bronne: 1 Maart 1988, Reeks 63 (Bde Sitrap 3: Ops/852/1 Mrt); Houer 89, Lêer [419]: Hooper Ops/Eme, deel 2, 9 Maart 1988, reeks 699, p 492.

6 SANWD, Pretoria, JFH, Houer 29, Lêer 142: Ops/384/20 Feb 88; Houer 90, Lêer 110: Op Packer, ongedateerd, reeks 37, pp 45-46; Houer 29, Lêer 152: Seinberig D OPS/309/4, 16 Maart 88, D OPS/Tak HK Rundu, pp 1-2; Houer 29, Lêer 152, ITSA/821/7 MRT 88, Sektor 20/SWAGM 21. 
ontruim sodat die manskappe ten minste droog kon slaap. Die magte het teen die middel van Maart aan die front gearriveer en daar is dadelik met finale voorbereidings en afronding vir die derde aanslag op Tumpo begin. Toenemende internasionale druk om uit Angola te onttrek, het verdere druk op die voorbereidings en afhandeling van Operasie Packer geplaas. ${ }^{7}$

Ter regverdiging van die voortgesette stryd het die SAW vyf redes aan die deelnemende leierskorps en troepe verskaf: Die MPLA is onwettig in Angola aan bewind; Angola word as hegte basis deur die USSR gebruik om teen die Republiek van Suid-Afrika (RSA) en SWA te veg; die USSR ondersteun die MPLA/FAPLA en die ANC; en UNITA dien as 'n bufferstrook vir aanvalle teen SWA en daarom veg die RSA indirek vir UNITA en direk vir die RSA. Dit het ook die geleentheid aan die SAW gegee om nuwe krygstuig op die proef te stel. Troepe is gewaarsku teen swak dissipline, gerugte, die vyandelike lugoormag en die hoë ongevalle weens geelsug en malaria. Geelsug was aansteeklik en daarom was persoonlike higiëne van uiterste belang en moes malariapille ook gereeld gedrink word. ${ }^{8}$

\section{OORGANGSFASE}

Die oorgangs- en onderhandelingsfase tussen Operasie Hooper en Packer, 2 tot 12 Maart 1988, is gekenmerk deur SAW-kwelaksies (onder andere steekaanvalle en kwelvuuraksies) teen die FAPLA-magte. Futiele grondskreeu-inisiatiewe, ondersteun deur die SAW-artillerie, is ook geloods. Só is die FAPLA-magte byvoorbeeld in Portugees gedreig: "Verlaat julle stellings en gaan na die wesoewer of staar die dood in die gesig." UNITA is ook effektief by kwelaksies betrek vóór die aanbreek van D-dag. Die ontruimde stellings van 59 FAPLA-Brigade is deur UNITA beset om te voorkom dat eersgenoemde dit weer inneem. UNITA het verder ook die logistieke FAPLA-konvooie aangeval. UNITA-magte is getaak om mynvelde op te spoor en onskadelik te stel. Teen 10 Maart het 4 Regular Bataljon van UNITA reeds sowat 200 myne opgespoor. Kompanies van 32 Bataljon is op 10 Maart ontplooi in die Chambinga-hoogland om uiteindelik met elemente van Regiment Groot Karoo te hergroepeer vir'n misleidingsaanval op Tumpo vanuit die suidooste. Vyandelike tussenaksies het onder andere lugdominering behels. Op 17 en 18 Maart was hulle besonder bedrywig in pogings om SAW-UNITA-posisies op te spoor en aan te val. Op 17 Maart het 'n aantal Angolese Mig-aanvalsvliegtuie 'n SAWkonvooi aangeval, maar die SAW-artillerie het voortgegaan met volgehoue treiteraksies. 'n Artillerie-fopstelling is deur die SAW ingerig om die vyandelike lugmag uit te lok om dit aan te val en laag genoeg oor die gebied te vlieg sodat die MiGs bestook kon word. ${ }^{10}$

7 Argief Regiment Mooirivier, Potchefstroom (ARMR), Lêer 275, H. Stark, Regiment Mooirivier oorlogsdagboek, 20 Februarie tot 2 Maart 1988, pp [1-2]; Onderhoud, G.J.J. Oosthuizen/W.H. van Zyl, 6.05.2001; ARMR, Potchefstroom, Oorlogsdagboek: M.G. Schoeman, 1RDLR Ops Packer, dae 2-3, 7-11; SANWD, Pretoria, JFH, Houer 92, Lêer [426]: Gesamentlike militêre aksies deur RSA en UNITA magte teen FAPLA magte in die Sesde Militêre Streek van Angola vanaf Desember 1987 tot Maart 1988, p 171.

8 ARMR, Potchefstroom: H. Stark, Regiment Mooirivier Oorlogsdagboek, 20 Februarie - 2 Maart 1988, pp [3-4].

9 SANWD, Pretoria, JFH, Houer 22, Lêer 82: Ops/862/3 Mrt 88; Houer 28, Lêer 137: Ops/890/88, 20 BDE HK/Tak HK Rundu, [3 Maart 1988]; OPS/891/88/05 Mrt 88, 20 Bde HK/Tak HK Rundu; OPS/899/07 Mrt 88, 20 Bd HK/Sek 20 Tak HK Rundu; OPS/916/08 Mrt 88, 20 BDE Tak HK/ Tak HK Rundu; OPS/922/09 Maart 88, 20 BDE HK/Tak HK Rundu; OPS/951/11Mrt 88, 20 BDE HK/Tak HK Rundu; OPS/952/12 Maart 88, 20 BDE HK/Tak HK Rundu; Houer 92, Lêer [426]: Gesamentlike militêre aksies ..., p 166.

10 SANWD, Pretoria, JFH, Houer 29, Lêer 152: Seinberig Ops/351/12 Mrt 88, Tak HK Rundu/SWA 31/32 BN; Houer 90, Lêer 110: Op Packer, ongedateerd, reeks 11, p 17, reeks 13-15, pp 19-20, 
20 Suid-Afrikaanse Gemeganiseerde Brigade (20 SA Meg Bde) het oor die tydperk 11 tot 14 Maart 1988 na die demobiliseringsgebied onttrek. Op 12 Maart het 82 SA Meg Bde aan die front gearriveer. Die volgende dag het die oorhandiging en oorname tussen 20 SA Meg Bde en 82 SA Meg Bde plaasgevind. Dieselfde dag het 20 SA Meg Bde Hoofkwartierstawwe en -personeel na Rundu vertrek en is Operasie Hooper formeel afgehandel. Die taktiese hoofkwartier van 82 SA Meg Bde, onder bevel van kolonel Paul Fouché, het dadelik met die beplanning van die derde aanval op Tumpo begin. ${ }^{11}$ Die Bevelvoerende Generaal SuidwesAfrika Gebiedsmag, generaal-majoor Willie Meyer, het beklemtoon dat die D-dag so gou doenlik, verkieslik in die omgewing van 20-22 Maart, moes plaasvind: Eerstens het die gesloerdery die FAPLA-magte bevoordeel aangesien hulle meer tyd gehad het om vir die aanval voor te berei deur onder andere die verbetering van verdedigingstellings. Daarbenewens kon die onsekere binnelandse en internasionale klimaat daartoe bydra dat die SAW moes onttrek voor die afhandeling van die taak. ${ }^{12}$

\section{BEPLANNING EN ONDERHANDELINGE MET UNITA}

Die opdrag aan 82 SA Meg Bde (Opso 1/88) het behels om, in samewerking met UNITA, die vyandelike magte oos van Cuito-rivier te vernietig of na die westekant van die Cuito-rivier te verdryf teen 20 Maart 1988. ${ }^{13} 82$ SA Meg Bde het dus voor die uitdaging te staan gekom om te slaag waar 20 SA Meg Bde misluk het. Die beperkende faktore vir SAW-UNITA-magte was egter steeds dieselfde, terwyl die voordele en gunstige faktore vir FAPLA en die Kubane ook grotendeels onveranderd gebly het. ${ }^{14}$

Die FAPLA-bondgenote was slaggereed om die derde Suid-Afrikaanse aanslag op Tumpo die hoof te bied. Dié magte was ingegrawe in "oorwoë verdedigingstelsels" en stewige bunkers het effektiewe beskerming gebied teen lugaanvalle en artilleriebombardemente. Boonop het die besondere kenmerke van die terrein en topografie die verdediging van Tumpo vergemaklik. Versterkings en logistieke voorsiening kon Tumpo met relatiewe gemak bereik. Verder is FAPLA enorm bevoordeel deur lugdominering en gevolglik is die SAW-UNITA-bondgenote op vele terreine daardeur beperk. FAPLA het met behulp van Russiese en Kubaanse raadgewers intensief gebruik gemaak van mynvelde om sodoende enige aanval op Tumpo te kanaliseer. SAWUNITA-bondgenote is byvoorbeeld gedwing om vanaf die noorde of noordweste of uit die suide aan te val. 82 SA Meg Bde het dus te make gehad met'n gedugte vyand, wie se moreel

reeks 22, p 24, reeks 26, pp 26-27; Houer 23, Lêer 89: Operasie-/Oorlogsdagboek, 20 Bde HK, Op Hooper, vol. 2, reeks 271, 275, 277, 288, 290.

11 SANWD, Pretoria, Houer 91, Lêer [124]: Ops Packer, ongedateerd, 13 Maart 1988, reeks 1 en 3; Houer 23, Lêer 89: Operasie-/Oorlogsdagboek van 20 Brigade Hoofkwartier, vol 2, reeks 302, 304, 308-309; Houer 90, Lêer 110: Op Packer, ongedateerd, reeks 20, p 22.

12 SANWD, Pretoria, JFH, Houer 29, Lêer 152: Seinberig Ops/350/09 MRT 88, SWAGM 31/Tak HK RU; Houer 92, Lêer [426]: Gesamentlike militêre aksies ..., pp 170-171; Houer 89, Lêer [419]: Hooper Ops/Eme, deel 2, 9 Maart 1988, reeks 687, pp 484-485; Houer 29, Lêer 142: Ops/823/09 Mrt 88.

13 SANWD, Pretoria, Houer 91, Lêer [124]: Ops Packer, ongedateerd, 24 Februarie 1988, reeks 2; 7 Maart 1988, reeks 1, 13 Maart 1988, reeks 1 [sic]; Houer 90, Lêer 110: Op Packer, ongedateerd, reeks $39, \mathrm{p} 47$.

14 SANWD, Pretoria, Houer 89, Lêer [419]: Hooper Ops/Eme, deel 2, 9 Maart 1988, reeks 700, pp 492-493. 
bowendien versterk is deur die twee mislukte SAW-UNITA-aanvalle op Tumpo. Die FAPLAbondgenote was vasberade om enige aanslag met alles tot hulle beskikking teen te gaan. ${ }^{15}$

Een van die grootste SAW-belemmeringe was uiters delikate logistieke probleme. Só byvoorbeeld was slegs vyf drywers teen 15 Maart beskikbaar en versoeke na Hoofkwartier Sektor 20 het niks opgelewer nie. Verskeie voertuie kon dus nie benut word nie en is daar gevolglik van lugvervoer gebruik gemaak om die situasie te beredder. ${ }^{16}$ Bydraende faktore wat 'n groot invloed op die effektiwiteit van die logistieke steunstelsel uitgeoefen het, was enersyds die swak toestand van die hooftoegangsroetes en andersyds die groot afstande tussen die derdelyn en tweedelyn logistieke installasies. Die afstand vanaf Pretoria na Grootfontein was byvoorbeeld 'n allemintige $2268 \mathrm{~km}$ per pad, $2829 \mathrm{~km}$ per spoor en $1243 \mathrm{~km}$ per lug. Boonop het die vyandelike lugoormag die logistieke steunstelsel erg gekortwiek. Daar moes van nagbeweging gebruik gemaak word, wat'n groot invloed uitgeoefen het op die beplanning, voorbereiding en tydsreëlings vir die lewering van kommoditeite. Daarbenewens het die nagbeweging oor uiters moeilike terrein, die lang afstande en swak roete-aanduiding tot gevolg gehad dat voertuie verdwaal het. Dit het heelwat vertragings teweeg gebring met die lewering van kommoditeite. Die spoed van konvooie is ook aansienlik verminder, terwyl die kwesbaarheid van konvooie vergroot is aangesien spoordissipline in talryke gevalle weens die swak roetes prysgegee moes word. ${ }^{17}$

UNITA is ook effektief by die beplanning betrek om hulle aandeel voor en tydens die operasie te finaliseer. Reeds op 6 Maart het samesprekings tussen die twee bondgenote plaasgevind en is besluit dat UNITA 'n skakeloffisier by 32 Bataljon sou plaas om die bataljon se operasies in die Anhara Lipanda, 'n bykans boomlose vlakte, ten opsigte van UNITA se ontplooiings te koördineer. Die 18 Semi Regular Bataljon van UNITA sou uit die gebied onttrek word en 5 Regular Bataljon moes in 59 Fapla-Brigade se ontruimde stellings ontplooi word. ${ }^{18}$ Op 10 Maart om 1300B het die 82 SA Meg Bde se beplanningstaf en 'n UNITA-afvaardiging onder leiding van ene kolonel Seta begin met die beplanning vir die derde aanslag op Tumpo. Die gevegsontwerp het die volgende behels:

"Fase 1: Eerste lig [misleidings]aanval deur 32 Bn op vy[andelike] stellings suid van Tumpo" en "Fase 2: Aanval deur pantser swaar mag op die vy[andelike] brughoof by Tumpo langs die noordelike toegangsweg. Gelyktydig met hierdie aanval moet UNITA wes van die rivier vy[andelike] stellings $\mathrm{N}$ en S aanval." Die volgende dag is die operasionele plan vir die Tumpo-aanval aan alle betrokke SAW-stawwe en ook aan die UNITA-afvaardiging aangebied. Die plan is deur brigadebevelvoerder kolonel Paul Fouché noodgedwonge aanvaar en 'n tevrede UNITA-afvaardiging het daarmee akkoord gegaan om hulle aksies, soos vervat in die plan,

15 SANWD, Pretoria, JFH, Houer 90, Lêer 110: Op Packer, ongedateerd, reeks 7, pp 13-15, reeks 34, p 36; Houer 92, Lêer [426]: Gesamentlike militêre aksies ..., p 173; SANWD, Pretoria, H SAW, Groep 4, Houer 62, Lêer HSAW/V/305/5, vol.1: Lesse geleer tydens konvensionele operasies in die westelike subteater. SA Leër [3 Maart 1990], p 2-17.

16 SANWD, Pretoria, JFH, Houer 29, Lêer 152: Seinberig Ops/916/15 Mrt 88, Tak HK RU/SWA GM 11; Houer 89, Lêer [419]: Hooper Ops/Eme, deel 2, 5 Maart 1988, reeks 677, p 480.

17 SANWD, Pretoria, H SAW, Groep 4, Houer 62, Lêer HSAW/V/305/5, vol.1: Lesse geleer tydens konvensionele operasies ..., pp 8-1, 8.2, 8-8.

18 SANWD, Pretoria, Houer 89, Lêer [419]: Hooper Ops/Eme, deel 2, 6 Maart 1988, reeks 680, p 481; Houer 90, Lêer 110: Op Packer, ongedateerd, reeks 21, p 23. 
uit te voer. ${ }^{19}$ Tydens die vergadering van 17 Maart is ontplooiing voor en op D-dag weereens intensief deur die bondgenote bespreek. ${ }^{20}$

Die SAW aanvalsplan, soortgelyk aan die tweede mislukte Tumpo-aanval (1 Maart 1988), het egter nie die ondersteuning van kolonel Paul Fouché en kommandant Gerhard Louw geniet nie. Hulle was albei onder andere besonder ontevrede om 'n nuwe aanval langs dieselfde roete te onderneem en was van oordeel dat die beperkte Tumpo-gebied nie geskik was vir aanvalle uit verskillende rigtings nie. Generaal Kat (André) Liebenberg het hulle egter beveel om voort te gaan. ${ }^{21}$

Die burgermageenhede het vroeg in Maart by die Brigade Administratiewe Gebied (BAG) aangekom en het daarvandaan na die opleidingsgebiede vertrek. Later het hulle na hul versamelgebiede beweeg. Die eerste groep wat deel was van die omruiling van troepe, was 'n $120 \mathrm{~mm}$ mortierbattery, wat op 5 Maart aan die front gearriveer het. ${ }^{22}$ Enkele dae later het Regiment Mooirivier ook na die opleidingsgebied beweeg, waar Regimente De la Rey en Groot Karoo reeds ontplooi was. Nadat die nodige proviand en watervoorraad ontvang is, het hulle verby die BAG beweeg. Regiment Mooirivier het kamp opgeslaan langs'n shona, sowat 800 meter van die hoof-logistieke roete na die front. Dié burgermageenheid het op 10 Maart die heel eerste kontak tydens Operasie Packer gemaak. Die manskappe het die geleentheid gehad om hulle klere te was en hulle wapens slaggereed te maak. Twee MiGs het skielik oor hulle gevlieg, omgedraai en reguit na hulle inbeweeg. Die betrokke lede van Regiment Mooirivier was vas daarvan oortuig dat die vliegtuie inbeweeg het om die finale slag te slaan, maar wonder bo wonder is nie 'n enkele skoot afgevuur nie en het die vliegtuie weer verdwyn. Die "aanval", so ver oos van Cuito Cuanavale, was'n sekere aanduiding dat die FAPLA-lugmag bereid was om aanvalle tot so ver suidoos as Mavinga te onderneem. ${ }^{23}$

Kort daarna het Regiment Mooirivier gehawende pantserkarre ontvang, waarvan sommige nie eens oor 'n toringluik beskik het nie. Die voertuie is gevolglik na die BAG geneem vir broodnodige herstelwerk. Die burgermageenhede en ongeveer 240 UNITA-infanteriste (laasgenoemde onder bevel van ene luitenant Ventura) het teen middel-Maart vir kernbelangrike opleiding aangemeld. Gedurende die kort en ontoereikende periode van 18 tot 22 Maart het hulle gesamentlike opleiding ter voorbereiding van Operasie Packer ontvang. Een van die opleidingsdae is opgeskort weens 'n gebrek aan diesel. ${ }^{24}$

Die opleidingsgeleenthede vir lede van die burgermageenhede was egter onvoldoende, onder andere as gevolg van die beperkte tyd voor D-dag en logistieke probleme. Kolonel A.

19 SANWD, Pretoria, JFH, Houer 23, Lêer 89: Operasie-/Oorlogsdagboek, 20 Bde HK, Op Hooper, vol. 2, reeks 299, 301; Houer 89, Lêer [419]: Hooper Ops/Eme, deel 2, 9 Maart 1988, reeks 490, pp 486-487; Houer 91, Lêer 124: Op Packer, ongedateerd, 11 Maart 1988, reeks 1.

20 SANWD, Pretoria, JFH, Houer 91, Lêer [124]: Ops Packer, ongedateerd, 17 Maart 1988, reeks 2.

21 L. Scholtz. 2013. Die SAW in die Grensoorlog 1966-1989. Kaapstad: Tafelberg, pp 359-360.

22 SANWD, Pretoria, JFH, Houer 92, Lêer [426]: Gesamentlike militêre aksies ..., p 169; Houer 90, Lêer 110: Op Packer, ongedateerd, reeks 17, p 21; Houer 89, Lêer [419]: Hooper Ops/Eme, deel 2, 4 Maart 1988, reeks 676, pp 478-479.

23 SANWD, Pretoria, JFH, Houer 92, Lêer [426]: Gesamentlike militêre aksies ..., p 171; Houer 90, Lêer 110: Op Packer, ongedateerd, reeks 18, p 21; Houer 89, Lêer [419]: Hooper Ops/Eme, deel 2, [10] Maart 1988, reeks 691, p 487; G.J.J. Oosthuizen. 2003. Semper Prorsum Regiment Mooirivier 1954 - 2001. Vanderbijlpark: Ons Drukkers, p 112.

24 SANWD, Pretoria, JFH, Houer 29, Lêer 152: Seinberig, D OPS/309/4/08 Mrt 88; H Lêer 31/ SWA GM 31, p 2; OPS/855/08 MRT 88, Tak HK RU/H Lêer 31 et al.; ARMR, Potchefstroom, Oorlogsdagboek: M.G. Schoeman, 1RDLR Ops Packer, dae 28-29; G.J.J. Oosthuizen: Semper Prorsum ..., p 112. 
Fourie was byvoorbeeld die mening toegedaan dat die burgermageenhede 'n geweldige agterstand gehad het, omdat hulle "nie jaarliks tov gesofistikeerde uitrusting opleiding ondergaan nie". Hulle was goed in die statiese rol maar hulle effektiwiteit in die meer mobiele situasie is as ontoereikend beskou. Die burgermageenhede se leiersgroep se paraatheid en "verroeste" ervaring was veral 'n groot bron van kommer vir die SAW-leierskorps. ${ }^{25}$ Op 14 Maart het kommandant Gerhard Louw van die SAW-gevegskool gevolglik oorgeneem as veggroepbevelvoerder, waarskynlik op grond van sy meerdere ervaring en omdat die aangewese Burgermag-bevelvoerder se huis oorstroom het en hy inderhaas moes terugkeer huis toe. Kommandant Boet Schoeman van die Regiment De la Rey was sy tweede-in-bevel. ${ }^{26}$

$\mathrm{Na}$ afloop van Operasie Packer is die bevelstruktuur terugverander soos dit was voor Louw bevel oorgeneem het. Die wisseling van bevel ten gunste van permanente SAW-lede het bitterheid by burgermagbevelvoerders veroorsaak. Dit was vir hulle 'n klinkklare bewys dat hulle vermoëns bevraagteken is. Daarbenewens is burgermaglede van onskatbare operasionele ondervinding ontneem. ${ }^{27}$ In 'n seinberig van 8 Maart 1988 is alreeds onomwonde verklaar: "Tov die mag wat agterbly [na voltooiing van Operasie Packer] moet dit verkieslik uit 32 BN [Bataljon] of 101 BN kom met, waar nodig, NDP [Nasionale Diensplig] spesialiste en nie uit burgermaggeledere nie." ${ }^{28}$

Die patroon om na 'n aanval te onttrek en sodoende aan die vyand die kans te gee om te herstel en om selfs hulle posisie te versterk, is ongelukkig noodgedwonge voortgesit. ${ }^{29}$ Daar is ook voortgegaan met die praktyk om nie die korrekte genie-stawwe, indien enige, by die onderskeie formasiehoofkwartiere te plaas nie. Genie-insette tydens die gesamentlike beplanning was ontoereikend en genie-beplanning op die onderskeie formasie- en eenheidsvlakke het nie daadwerklik vanaf die aanvang van die beplanningsproses deel uitgemaak van die betrokke beplanningsgroep nie. Dit was veral die gebrek aan genie-stafoffisiere by formasieen eenheidhoofkwartiere wat daartoe gelei het dat beplanning, koördinering en bevel en beheer nie na wense uitgevoer is nie. ${ }^{30}$

Betroubare inligting speel 'n primêre rol tydens enige konvensionele operasie. Baie van die suksesse wat tydens vorige operasies behaal is, was onder andere te danke aan goeie inligting, maar heel dikwels was van die grootste frustrasies te wyte aan veral onbetroubare UNITA-inligting. Tydens vorige operasies en veral Operasie Packer moes veggroepe dikwels aanvalle uitvoer op teikens waaroor onvoldoende inligting beskikbaar was. ${ }^{31}$ Volgens UNITA-

25 SANWD, Pretoria, JFH, Houer 29, Lêer 152: Seinberig D Pant/775/10 Mrt 88, H Lêer 64/Tak HK RU, Seinberig D Ops/309/4 Op Packer, H Lêer 31/SWA GM 31, Tak HK RU, 11 Maart 1988; W. Steenkamp \& H. Heitman. 2016. Mobility conquers. The story of 61 Mechanised Battalion Group, 1978-2005. Solihull England: Helion and Company, p 983.

26 Onderhoud, G.J.J. Oosthuizen/W.H. van Zyl, 6.05.2001; SANWD, Pretoria, JFH, Houer 29, Lêer 152: Seinberig OPS/793/12 Mrt 88, Tak HK Rundu/H Lêer 31 et al.; ARMR, Potchefstroom, Oorlogsdagboek: M.G. Schoeman, 1RDLR Ops Packer, dag 24; W. Steenkamp \& H. Heitman. 2016. Mobility conquers. The story of 61 Mechanised Battalion Group, 1978-2005. Solihull England: Helion and Company, p 868.

27 Onderhoud, G.J.J. Oosthuizen/J.M. van Zyl, 8.02.2002.

28 SANWD, Pretoria, JFH, Houer 29, Lêer 152: Seinberig D OPS/309/4/07 MRT 88, H Lêer 31/ SWAGM 31, pp 2-3.

29 SANWD, Pretoria, Houer 89, Lêer [419]: Hooper Ops/Eme, deel 2, 9 Maart 1988, reeks 701, p 493.

30 SANWD, Pretoria, H SAW, Groep 4, Houer 62, Lêer HSAW/V/305/5, vol.1: Lesse geleer tydens konvensionele operasies ..., pp 6-2, 6-10.

31 SANWD, Pretoria, H SAW, Groep 4, Houer 62, Lêer HSAW/V/305/5, vol.1: Lesse geleer tydens konvensionele operasies ..., pp 13-1, 13-6. 
inligtingsbronne was 'n Kubaanse regiment wes van die samevloeiing van die Cuito- en Cuanavale-rivier ontplooi en was verdere Kubaanse versterkings vanaf Menongwe na Cuito Cuanavale onderweg. ${ }^{32}$ UNITA as inligtingsbron is egter tereg beskryf as “...vaag, veroudend [sic] en 'n bron van verwarring". ${ }^{33}$

Die Suid-Afrikaanse Lugmag (SALM) is ernstig aan bande gelê deur die bykans onophoudelike lugverkenning van die FAPLA-lugmag oor die front. Aanvalle deur die SAL op die FAPLA-verdedigingstellings op 20 en 21 Maart het byvoorbeeld nie veel vermag nie. ${ }^{34}$ Die FAPLA-lugoormag was so deurslaggewend dat die beplande aandkerkdiens van 18 Maart afgelas is as gevolg van MiG-aktiwiteite. ${ }^{35}$

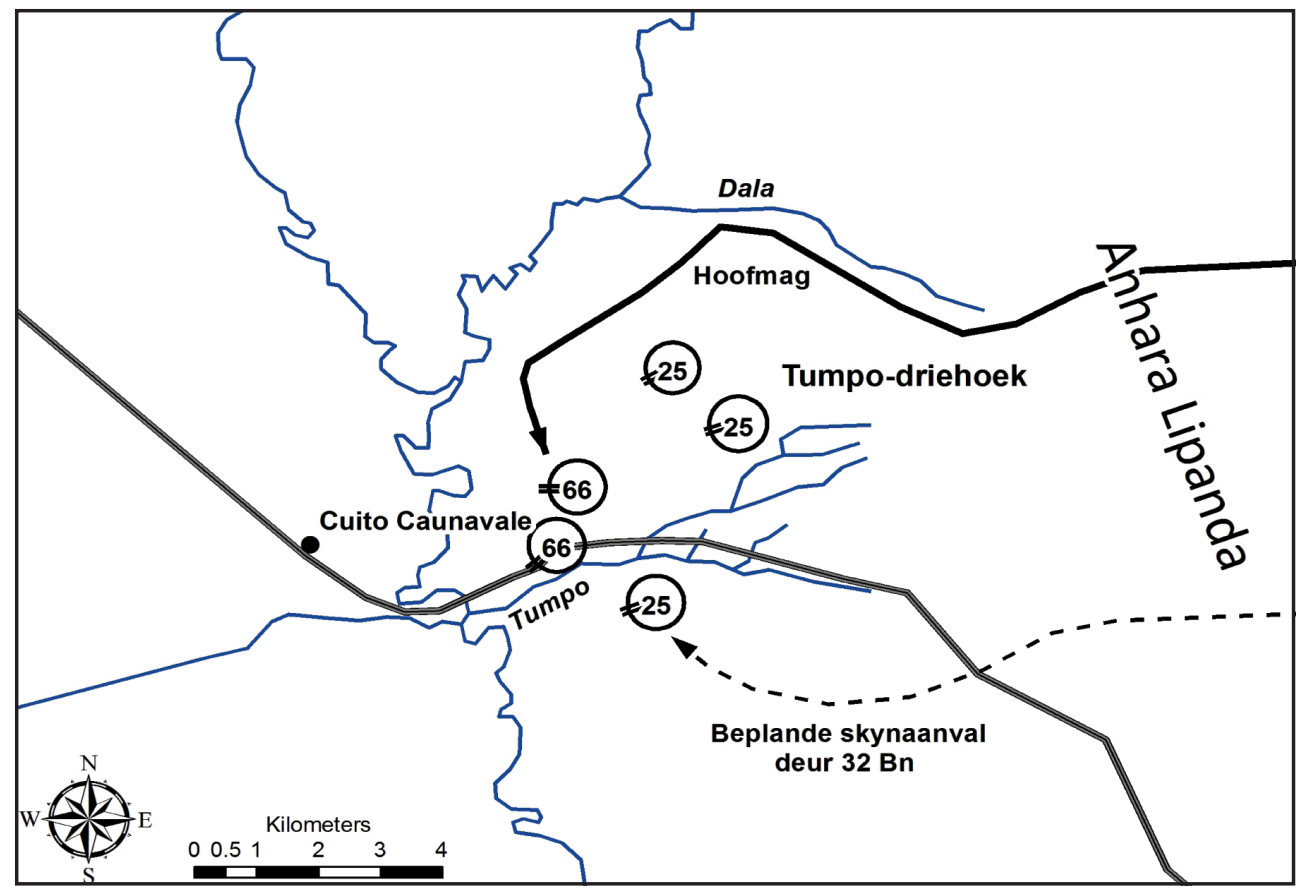

Die Tumpo-driehoek, Suidoos-Angola, Maart $1988^{36}$

SANWD, Pretoria, JFH, Houer 90, Lêer 110: Op Packer, ongedateerd, reeks 35, p 43.

SANWD, Pretoria, H SAW, Groep 4, Houer 62, Lêer HSAW/V/305/5, vol.1: Lesse geleer tydens konvensionele operasies..., p 3-10.

34 SANWD, Pretoria, JFH, Houer 90, Lêer 110: Op Packer, ongedateerd, reeks 27-28, p 27.

35 SANWD, Pretoria, Houer 91, Lêer [124]: Ops Packer, ongedateerd, 18 Maart 1988, reeks 2.

36 L. Scholtz. 2013. Die SAW in die Grensoorlog 1966-1989. Kaapstad: Tafelberg, p 349; D. Williams. 2008. On the border: The white South African military experience 1965-1990. Cape Town: Tafelberg, p 106; F. Bridgland. 1993. The war for Africa: Twelve months that transformed a continent. Rivonia: Ashanti, p 258. 


\section{D-DAG, 23 MAART 1988}

Die hoofaanvalsmag, onder aanvoering van kommandant Gerhard Louw, het onder andere bestaan uit Regiment President Steyn (24 Olifanttenks), Regiment Mooirivier (Ratel 90-eskadron) en twee gemeganiseerde infanteriebataljons van Regimente De la Rey en Groot Karoo. Daarbenewens het verskeie UNITA-bataljons dié aanvalsmag versterk. 82 SA Meg Bde was op 22 Maart "slaggereed" vir die derde aanval op Tumpo. Aanvanklik het alles seepglad verloop. Die eerste voorspan van Regiment De la Rey het reeds om 0600B na hulle versamelgebied beweeg en die beweging van die hoofaanvalsmag en Regiment Groot Karoo het ook volgens plan verloop. Daarbenewens het die taktiese bevelvoerder, kolonel Paul Fouché, en die taktiese hoofkwartier op 01:30 (D-dag) die hoë terrein noord van die Chambingarivier bereik om daarvandaan die aanval te beheer. ${ }^{37}$

Die skynaanval deur 32 Bataljon en elemente van Regiment Groot Karoo het die opstelling van 'n fopbrughoof suid van Cuito Cuanavale behels. Die FAPLA-bondgenote het hulle egter weinig daaraan gesteur en bykans alle fokus toegespits op die aankomende hoofaanvalsmag, wat vanuit die noordooste die aanval geloods het. ${ }^{38}$

Om 21:00 dieselfde nag is met die aanmars na Tumpo begin. 'n Klein gloeistafie was onderaan elke voertuig gemonteer om die nagbeweging te vergemaklik. Die nagbeweging het egter rampspoedig begin aangesien die verkenners, wat ook as gidse opgetree het, die pad byster geraak het. Die voorste tenks het gevolglik verdwaal en op die agterste tenks afgepyl. In'n poging om die chaos onder beheer te bring, het die tenks lank staties gebly.'n Ander faktor wat die aanmars erg aan bande gelê het en veroorsaak het dat heelwat tyd verspil is, was 'n stuk hoë grond met sanderige steil hellings, bekend as "heart break hill". Die tenks het met relatiewe gemak die hindernis baasgeraak, maar verskeie Ratels het vasgeval en moes met die tenkherwinningsvoertuig uitgesleep word. Boonop is die UNITA-soldate wat reeds vir'n paar dae strategiese hoë grond beset het om geskikte observasieposte vir SAW-artillerie te vestig, deur FAPLA-magte verdryf tydens die SAW-UNITA-aanmars. Daarbenewens het die SAWartillerie verskeie voertuigprobleme ondervind. As gevolg van hierdie faktore het die aanvalsmag nie beskik oor die noodsaaklike artillerie-observasieposte nie, en die artillerievuur op die doelwit was gevolglik ondoeltreffend en onakkuraat. ${ }^{39}$

Kort na 07:30 het een van die voertuie wat'n tenkroller vervoer het, omgeslaan. Met slegs een oorblywende tenkroller tot die aanvalsmag se beskikking om die mynvelde te bres, het beweging heelwat stadiger plaasgevind. Die FAPLA-magte het die SAW-bondgenote boonop met artillerie bestook en hoewel dit onakkuraat was, het dit nogtans groot gevaar ingehou vir die infanterie wat die pad voor die voertuie moes vee. Die hoofaanvalsmag het stadig vorentoe beweeg, terwyl die artillerie voor bombardemente op die teiken geloods het. Met die bereiking van die afmarslyn om 08:15 was twee G5-kanonne ook ondiensbaar, weens meganiese probleme. ${ }^{40}$

Die aanvalsmag het te ver wes beweeg en het hulle byna op die rand van die Cuito-rivier se vloedvlakte bevind. 'n Uitgestrekte mynveld moes toe getrotseer word met slegs een mynroller

37 SANWD, Pretoria, JFH, Houer 90, Lêer 110: Op Packer, ongedateerd, reeks 42, 46-53, pp 49-50, 60-64; Kyk ook P Nortje. 2003. 32 Battalion: The inside story of South Africa's elite fighting unit. Cape Town: Zebra Press, p 247. SANWD, Pretoria, JFH, Houer 90, Lêer 110: Op Packer, ongedateerd, reeks 44-45, pp 59-60, reeks 56, p 66.

39 Onderhoud, G.J.J. Oosthuizen/W.H. van Zyl, 6.05.2001; ARMR, Potchefstroom, Oorlogdagboek: M.G. Schoeman, 1RDLR Ops Packer, dae 32-33.

40 Onderhoud, G.J.J. Oosthuizen/W.H. van Zyl en H. Stark, 6.05.2001; SANWD, Pretoria, JFH, Houer 90, Lêer 110: Op Packer, ongedateerd, reeks 54-55, pp 64-65. 
tot hulle beskikking. Die gevaar van teentenkmyne was gevolglik baie groot en om 08:35 het een van die SAW-tenks 'n teentenkmyn en twee personeelmyne afgetrap. Die beskadigde en onbruikbare tenk is deur die herwinningspanne herwin. Die SAW-artillerie het om 08:40 met 'n ondersteuningsvuurplan begin, want die SAW-tenks was voor die mynveld en FAPLA-artillerie het op hulle gefokus. Sowat tien minute later het die SAW-aanvalsmag by die mynveld vasgeval. Tevergeefse pogings is aangewend om met twee plofadders die mynveld te bres. Pogings om die myne met behulp van springstof te detoneer, was ook onsuksesvol. FAPLA-tenks het om 10:07 vanaf die wesoewer op die aanvalsmag gevuur. Kort daarna het die SAW-tenks die vuur beantwoord en in die proses een tenk vernietig. Die SAW-bombardement was so geslaagd dat daar skielik geen vuur op die aanvalsmag neergebring is nie. ${ }^{41}$

UNITA se 66 en 75 Regular Bataljons het intussen soos beplan met hulle aanval wes van die Cuito-rivier (Bambi-gebied) voortgegaan. Die FAPLA-magte het UNITA egter met BM 21-vuur gekonfronteer en UNITA kon bloedweinig uitrig. ${ }^{42}$

Die hoofaanvalsmag het uit radeloosheid probeer om die plofadders met Ratelmasjiengeweervuur te detoneer. Dit het ook misluk want in die proses het een Ratel'n landmyn afgetrap. Kommandant Louw het gevolglik besluit om voortaan gebruik te maak van die mynroller, gevolg deur die tenks, om 'n bres in die mynveld te slaan. Met die mynroller is sodanige sukses behaal dat een tenkeskadron teen 12:00 reeds deur die mynveld begin beweeg het. In reaksie hierop het die FAPLA-magte hewige vuur op die SAW-voertuie neergebring. Teen 12:30 het een tenkeskadron reeds deur die mynveld beweeg. Die SAW het egter sulke hewige vuur getrek dat kommandant Louw besluit het om na dooie grond terug te beweeg. UNITA-troepe wat bo-op die tenks ontplooi was, het swaar verliese gely. Boonop het die FAPLA-magte begin om $23 \mathrm{~mm}$-lugafweerkanonne in te span, wat vanaf die oostelike flank begin vuur het. ${ }^{43}$

Die voorste eskadron het teen 12:45 weer beweeg, maar het onmiddellik hewige artillerievuur, veral vanaf die wesoewer, ondervind. Die vuur was so hewig dat die aanvalsmag eenvoudig nie vorentoe kon beweeg nie. Boonop was die vasgepende aanvalsmag in groot gevaar toe die MiGs teen 13:30 bokant hulle bedrywig begin raak het. Die aanvalsmag was egter vasberade om ondanks die hewige artillerievuur en die moontlikheid van 'n lugaanval vorentoe te beweeg. Weens onbetroubare UNITA-inligtingsbronne was die aanvalsmag nie bewus van die tweede mynveld nie, en om 13:46 het hulle in dié mynveld vasgery. Twee SAW-tenks is geïmmobiliseer weens beskadigde veerstelsels. In daardie stadium het FAPLAmortiere orals tussen die SAW-tenks geval, wat die sig tot die minimum beperk het. Groot onsekerheid het geheers oor waar die mynveld was, en of dit myne of mortiere was wat tussen hulle ontplof het. Die SAW se artillerievermoë is nadelig beïnvloed deur die reën en mis, aangesien waarneming op die front en doelwit daardeur bemoeilik is. Daarenteen het die FAPLA-magte ondanks die swak sig die aanvalsmag met akkurate en vernietigende vuur effektief verhoed om verder as die tweede mynveld te vorder. ${ }^{44}$

${ }_{41}$ E. George. 2005. The Cuban intervention in Angola, 1965-1991. From Che Guevara to Cuito Cuanavale. New York: Frank Cass, p 233; SANWD, Pretoria, JFH, Houer 90, Lêer 110: Op Packer, ongedateerd, reeks 57-62, pp 67-70.

42 SANWD, Pretoria, JFH, Houer 90, Lêer 110: Op Packer, ongedateerd, reeks 63, p 70.

43 SANWD, Pretoria, JFH, Houer 91, Lêer [124]: Ops Packer, ongedateerd, 23 Maart 1988, reeks 36; Houer 90, Lêer 110: Op Packer, ongedateerd, reeks 64, pp 70-71, reeks 67-68, pp 72-73.

44 Onderhoud, G.J.J. Oosthuizen/W.H. van Zyl en H. Stark, 6.05.2001; SANWD, Pretoria, JFH, Houer 90, Lêer 110: Op Packer, ongedateerd, reeks 69-71, pp 73-75, reeks 80, pp [79-80]. 
Kommandant Louw het om 13:48 gerapporteer dat die dieselvlakke so laag was dat die gevaar bestaan het dat die aanvalsmag nie die voorversamelgebied sou kon bereik nie. Sy voorstel dat die aanvalsmag liewers moes onttrek, het aanvanklik op dowe ore geval. Kort na dié versoek is 'n derde tenk so beskadig dat dit ondiensbaar was. ${ }^{45}$ Teen 14:00 het die aanvalsmag deur die tweede mynveld beweeg. Die FAPLA-vuur was besonder hewig. Kolonel Fouché het daarom opdrag gegee dat daar na die omgewing van die eerste mynveld onttrek moes word en dat die tenks terselfdertyd herwin moes word. Om 14:05 is die aanvalsmag beveel om na die voorversamelgebied te onttrek. Tydens die onttrekking het MiGs vanuit die suide die aanvalsmag aangeval. Geen verliese is egter gely nie aangesien al die bomme van teiken af was. Die terugtrekking het daarna sonder verdere voorvalle voortgegaan. Die beskadigde tenks moes egter op die slagveld agtergelaat word weens hewige FAPLA-vuur. Louw en Fouché wou die tenks met artillerievuur vernietig, maar is deur 'n onnadenkende Kat Liebenberg verbied. Hy het beveel dat die tenks later herwin kon word. Die dag na afloop van Operasie Packer het 'n verkenningspan egter die futiele opdrag gekry om die drie SAW-tenks ${ }^{46}$ te vernietig. ${ }^{47}$

Kolonel Fouché en sy senior kollegas het teen 18:39 besluit dat daar na die taktiese hoofkwartiergebied terugbeweeg moes word. Terselfdertyd het die onderskeie SAW-magte na hulle aangewese versamelgebiede vertrek. Verdere optrede sou bepaal word tydens die nabetragting van die operasie. UNITA is betrek by die beplanningsaksies en generaal Demostinos het onder meer op 25 en 26 Maart met kolonel Fouché vergader om te besluit oor gesamentlike optrede. ${ }^{48}$

Ronald Dreyer vertolk tereg die onttrekkingversoek en -bevel as volg: "The South African commander asked for permission '... to break off the attack', a euphemism for acknowleding military defeat." 49

Kolonel Fouché het nogtans die gedemoraliseerde veggroep hartlik bedank vir die taak wat hulle verrig het. Hy het hulle bemoedig deur onder andere te beweer "... die boere het nie verloor nie [sic!]. Sy stawwe is alreeds besig om weer te beplan.” Enkele dae later (29 Maart) het die veggroepbevelvoerder egter die opdrag gekry om teen 8 April 1988 te onttrek. ${ }^{50}$

Die SAW-UNITA-troepe se moreel het 'n laagtepunt bereik na die derde mislukte poging. Na die suksesvolle verdediging van Tumpo en die buit van drie SAW-tenks, was die FAPLAmoreel daarenteen op 'n besondere hoogtepunt. Die tenks wat deur die SAW agtergelaat is, het sterk propaganda-waarde vir die FAPLA-magte gebied. Een van die tenks is na 25 Bataljon se stellings gesleep terwyl die ander deur stellings beskerm is om te verhoed dat die SAW-magte

45 SANWD, Pretoria, JFH, Houer 90, Lêer 110: Op Packer, ongedateerd, reeks 72, pp 75-76.

46 Steenkamp verskaf'n bestekopname van lewensverliese en verlies aan toerusting tydens Operasies Moduler en Hooper en sluit foutiewelik die drie tenks, wat tydens Operasie Packer in FAPLA se besit beland het, in. Kyk W. Steenkamp. 2016, Suid-Afrika se grensoorlog 1966-1989. Kaapstad: Tafelberg, p 270.

47 ARMR, Potchefstroom, Oorlogsdagboek: M.G. Schoeman, 1RDLR Ops Packer, dag 34; SANWD, Pretoria, JFH, Houer 90, Lêer 110: Op Packer, ongedateerd, reeks 73-74, pp 76-77; W. Steenkamp \& H. Heitman. 2016. Mobility conquers. The story of 61 Mechanised Battalion Group, 1978-2005. Solihull England: Helion and Company, p 872.

48 SANWD, Pretoria, Houer 91, Lêer [124]: Ops Packer, ongedateerd, 25 Maart 1988, reeks 2, 26 Maart reeks 1; Houer 90, Lêer 110: Op Packer, ongedateerd, reeks 77, 85, 94, 99, pp 78, 83, [89, 92]; L. Scholtz. 2013. Die SAW in die Grensoorlog 1966-1989. Kaapstad: Tafelberg, p 364. R. Dreyer. 1994. Namibia and Southern Africa. Regional dynamics of decolonization 1945-90. London and New York: Kegan Paul International, p 173. 
dit bereik. Buitelandse joernaliste is selfs ingevlieg om die SAW-tenks te besigtig. Daarbenewens is van grondskreeu-apparaat gebruik gemaak om wyd en syd te verkondig dat die drie tenks in FAPLA-hande is en dat een Afrikaanssprekende SAW-soldaat gevange geneem is. ${ }^{51}$

Die SAW het, net soos in vorige operasies, nie die belangrikheid van sielkundige ontlonting besef nie. Heelwat getraumatiseerde SAW-soldate het aan post-traumatiese stres gely, wat'n demper geplaas het op hulle lewenslus. ${ }^{52}$

UNITA het ernstige personeelverliese gely, veral onder die troepe wat saam met die tenks beweeg het. Daarbenewens het heelwat soldate van die twee UNITA-bataljons wat op die wesoewer aangeval het, gesneuwel. Daarteenoor het die SAW-magte geen verliese gely nie..$^{53}$ Die oogmerk om SAW-verliese tot die minimum te beperk deur die maksimale aanwending van UNITA-troepe is dus met ongekende sukses bekroon.

Terwyl die nabetragting aan die gang was, het albei vyandelike groepe kwelaksies uitgevoer. Die SAW het voortgegaan met artilleriebestokings op strategiese en geleentheidsteikens. Die volgehoue teistering van die SAW-UNITA-magte deur die MiGs het veroorsaak dat die SAW-artillerie nie doeltreffend kon voortgaan met bestokings nie. Die FAPLA-magte het ook inderhaas Cuito Cuanavale se verdediging verskerp. Hulle was van oordeel dat die SAW-UNITA-magte met die volgende aanval op dié teiken sou fokus. Daar is byvoorbeeld 49 tenks op die oosoewer ontplooi en nuwe stellings is ingerig vir SAM-grond-tot-lug-missiele, tenks en 23 mm-kanonne langs die pad vanaf Sabiano na Cuito Cuanavale. Teen die einde van Maart het die eerste eenhede wat aan Operasie Packer deelgeneem het, begin terugkeer na hulle basisse. Tot en met die finale onttrekking van die Suid-Afrikaanse magte in April 1989 is die status quo gehandhaaf, wat as 'n skaakmatsituasie beskryf kan word. ${ }^{54}$ Die Kubane en Russe het egter daarop aanspraak gemaak dat hulle betrokkenheid in Angola gelei het tot die "forced [sic] withdrawal" van die SAW uit Angola, veral na die "military defeats [sic] of March-June 1988." Die Angolese bondgenote was boonop verkeerdelik van oordeel dat die SAW Cuito Cuanavale wou verower en dat die Angolese bondgenote die sogenaamde "Slag van Cuito Cuanavale" gewen het. ${ }^{55}$

51 M. Jùnior, Forças Armadas Populares de Libertação de Angola. 1. Excésito Nacional (19751992). Lisboa: 2007. Prefácio, p 125; G. Shubin \& A. Tokarev (eds). 2011. Bush war: The road to Cuito Cuanavale, Soviet soldiers' accounts of the Angolan war. Johannesburg: Jacana Media, pp 169-170; SANWD, Pretoria, JFH, Houer 90, Lêer 110: Op Packer, ongedateerd, reeks 78, pp 78-[79], reeks 82, pp [80-81], reeks 89-90, pp [86-87]; Kyk ook J. Geldenhuys. 1995. A general's story: From an era of war and peace. Johannesburg: Jonathan Ball Publishers, pp 221-222; H. Hamann. 2001. Days of the generals. The untold story of South Africa's apartheid-era military generals. Cape Town: Zebra press, p 96.

52 SANWD, Pretoria, H SAW, Groep 4, Houer 62, Lêer HSAW/V/305/5, vol. 1: Lesse geleer tydens konvensionele operasies ..., pp 14-1, 14-3.

53 E. George. 2005. The Cuban intervention in Angola, 1965-1991. From Che Guevara to Cuito Cuanavale. New York: Frank Cass, p 234; SANWD, Pretoria, JFH, Houer 90, Lêer 110: Op Packer, ongedateerd, reeks 83, $\mathrm{p}$ [81].

54 SANWD, Pretoria, JFH, Houer 29, Lêer 152: D OPS/309/4 Op Packer, H. Lêer 31/SWA GM 31, 16 Mrt 88; Houer 90, Lêer 110: Op Packer, ongedateerd, reeks 85-118, pp 83-103; ARMR, Potchefstroom, Oorlogsdagboek: M.G. Schoeman, 1RDLR Ops Packer, dae 46, 48; G. Shubin \& A. Tokarev (eds). 2011. Bush war: The road to Cuito Cuanavale, Soviet soldiers'accounts of the Angolan war. Johannesburg: Jacana Media, p 31; C. Holt. 2005. At thy call we did not falter. Cape Town: Zebra Press, p 138.

55 G. Shubin \& A. Tokarev (eds). 2011. Bush war: The road to Cuito Cuanavale, Soviet soldiers' accounts of the Angolan war, Johannesburg: Jacana Media, pp 7, 187; E. George, E. 2005. The Cuban intervention in Angola, 1965-1991. From Che Guevara to Cuito Cuanavale. New York: 
Intussen was die vredesamesprekings tussen belanghebbende partye goed op koers. Verteenwoordigers van Suid-Afrika, Kuba en Angola het op 22 Augustus 1988 'n wapenstilstandsooreenkoms gesluit te Ruacana in Suidwes-Afrika (Namibië). Voortgesette onderhandelinge het daartoe gelei dat die implementering van resolusie 435 en die onttrekking van die Suid-Afrikaanse magte uit Suidwes-Afrika goedgekeur is. Laasgenoemde ooreenkoms moes vanaf 1 April 1989 tot en met die onafhanklikwording van Suidwes-Afrika geïmplementeer word. 'n Verdere ooreenkoms tussen Kuba en Angola het die onttrekking van Kubaanse magte binne 27 maande uit Angola behels. Die ooreenkomste het die weg gebaan vir 'n vreedsame afsluiting van die sogenaamde Suidwes-kwessie. ${ }^{56}$

\section{TEN SLOTTE}

Die derde aanval op Tumpo was 'n volslae mislukking. Die SAW-magte is deur hewige vuur vasgepen en so verhoed om enige vyandelike doelwitte te verower. Weens die reën en mis was daar aanvanklik nie 'n MiG-lugbedreiging nie, en die FAPLA-magte het die SAW-aanval afgeweer sonder om enige fisiese kontak te mak.

'n Logistieke stelsel moet met die aanvang van enige operasie gevestig word om eskalasie te hanteer, maar in hierdie geval is geen oorwoë logistieke stelsel gevestig of aangepas om bestaande knelpunte te hanteer nie. In plaas daarvan is die logistieke stelsel op 'n ad hoc-basis ontwikkel en is dit regdeur die operasie op 'n krisisbasis bedryf. Regiment Mooirivier het byvoorbeeld gehawende voertuie ontvang wat inderhaas herstel moes word, en twee G5kanonne van die hoofaanvalsmag het weens meganiese probleme onbruikbaar geword. 'n Nypende dieseltekort het ook veroorsaak dat een dag van die reeds ontoereikende vyfdagopleidingsgeleentheid van die burgermageenhede opgeskort moes word. Tot oormaat van ramp moes die hoofaanvalsmag weens onder andere lae dieselvlakke onttrek. Die plofadders is, net soos in voorafgaande operasies, onsuksesvol aangewend om die mynvelde vinnig en veilig te bres.

Slegs vyf dae is gereserveer vir die voorbereiding en opleiding van burgermageenhede, en een van daardie vyf dae moes bowendien opgeskort word weens die ernstige dieseltekort. Dié ongewenste toedrag van sake het spanning veroorsaak, wat vererger is deur die openlike wantroue wat staandemagoffisiere geopenbaar het in die konvensionele vermoëns van die burgermageenhede, deur onder andere sommige burgermagbevelvoerders met staandemaglede te vervang. Gegewe die beperkte kontak, kon die staandemagbevelvoerders voorts ook nie 'n doeltreffende vertrouensverhouding met lede van die burgermageenhede opbou nie. Die toedrag van sake het bygedra tot die negatiewe uitkoms van die derde aanslag op Tumpo.

Gebrekkige intelligensie het ook'n dodelike impak op die derde aanval gehad. Die UNITAinligting was onbetroubaar en boonop het die SAW-verkenningselemente ook verskeie "inligtingstiltes" ervaar. Albei was byvoorbeeld totaal onbewus van die tweede mynveld, met

Frank Cass, pp 234-235; W. Steenkamp \& H. Heitman. 2016. Mobility conquers. The story of 61 Mechanised Battalion Group, 1978-2005. Solihull England: Helion and Company, p 867.

$56 \quad$ P. Gleijeses. 2013. Visions of freedom. Havanna, Washington, P and the struggle for Southern Africa, 1976-1991. Chapel Hill: University of North Carolina Press, pp 450-492; C.J. Nöthling, "Kort kroniek van militêre operasies en optredes in Suidwes-Afrika en Angola (1914-1988)", Militaria, 19/2, 1989, pp 17-18; Kyk ook Rapport, 1988.05.01, p 2; Die Volksblad, 1988.06.27, p 8; Die Transvaler, 1988.07.11, p 20; The Star, 1988.05.02, p 7; The Cape Times, 1988.06.30, p 6; Beeld, 1988.05.05, p 2; Die Burger, 1988.07.01, p 12, 1988.07.21, p 16. 
katastrofale gevolge. Daarbenewens het veral UNITA-gidse soms op uiters kritieke tye weens gebrekkige kennis van die terrein en tydens nagbeweging totaal die spoor byster geraak. Dit het bygedra tot tydverspilling, onsekerheid en spanning.

Die Breytenbach-aanspraak dat Tumpo tydens die derde probeerslag verower is en dat daardeur onomwonde gedemonstreer is dat goed beplande, effektiewe aanvoering en deeglik gekoördineerde nagaanvalle deur goed opgeleide infanteriste selde misluk, is derhalwe van alle waarheid ontbloot. Dit was buitendien nie 'n nagaanval nie, maar het helder oordag plaasgevind. Die derde aanval op Tumpo op 23 Maart 1988 kan sonder vrees vir teenspraak as 'n klaaglike mislukking beskou word.

Verskeie faktore het die derde aanslag op Tumpo gekelder: 'n Gebrek aan kreatiewe denke, deur bykans dieselfde aanvalsplan en aanmarslyn van die mislukte tweede Tumpo-aanval te herhaal ('n fatale taktiese flater en strydig met algemeen geldende aanvalstrategieë); die gebrek aan 'n oorwoë logistieke stelsel (byvoorbeeld die tekort aan diesel en meganiese paraatheid van voertuie en toerusting); deeglik verskansde en toegeruste FAPLA-magte; ontoereikende intelligensie (veral betreffende die tweede mynveld); bykans onbegaanbare sanderige en digbeboste terrein; onbemande observasieposte; bykans totaal ontoereikende voorbereiding en opleiding van burgermageenhede; die gespanne en gebrekkige vertrouensverhouding tussen burgermageenhede en SAW-staandemagoffisiere; en internasionale druk om uit Angola te onttrek. 